\title{
Studies on Glucagon Receptor and Antagonists of Glucagon Receptor for the Management of Diabetes Mellitus
}

\author{
Ghulam Abbas ${ }^{1,2 *}$, Ahmed Al Harrasi ${ }^{2 *}$ and Hidayat Hussain ${ }^{2}$ \\ ${ }^{1}$ Department of Biological Sciences and Chemistry, University of Nizwa, Oman \\ ${ }^{2}$ Chair of Oman's Medicinal Plants and Marine Natural Products, University of Nizwa, Oman
}

Submission: January 16, 2018; Published: January 29, 2018

*Corresponding author: Ghulam Abbas, Department of Biological Sciences and Chemistry, University of Nizwa, Nizwa, Oman, Tel: +968-94354364; Fax: +968-25443400; Email: abbashej@unizwa.edu.om

Ahmed Al Harrasi, Chair of Oman’s Medicinal Plants and Marine Natural Products, University of Nizwa, Nizwa, Oman, Email: ahararsi@unizwa.edu. om

\begin{abstract}
Glucagon receptor plays an important role in the glucose homeostasis and thus is drug target for the management of hyperglycemia in type-2 diabetes mellitus. The suppression of glucagon secretion from the alpha-cells is the key to control hyperglycemic condition. The identification of non-peptide antagonists of glucagon receptor is an effective therapeutic approach to inhibit the glucagon secretion to achieve normal glucose index.
\end{abstract}

Keywords: Glucagon receptor; Hyperglycemia; Diabetes mellitus; Antagonists

\section{Introduction}

\section{Background}

Diabetes mellitus is a chronic metabolic disorder which is spreading at an alarming rate all over the world. Glucagon receptor belongs to the G protein-coupled receptors (GPCRs) superfamily and an important drug target for type-2 diabetes [1]. G-Proteins (guanine nucleotide binding proteins) actually act as molecular switches to turn on intracellular signaling as a result of GPCRs activation by intracellular stimuli. The GPCRs are also known as membrane bound receptors $[2,3]$.

Both rat and mouse glucagon receptors are composed of 485-amino acids while the human glucagon receptor contains 477 amino acids (62kDa) and seven transmembrane (7TM) domain proteins [4]. The human glucagon receptor is little shorter and about $80 \%$ identical to the mouse receptor. The structure-function studies revealed that all seven transmembrane helices are essential for the process of receptor folding and transporting to cell surface. Moreover, it is observed that the pattern of glycosylation may have a critical role in ligand recognition. Hence, for ligand binding, extracellular portion (intact $\mathrm{N}$-terminal) of the receptor is required. It is found that carboxyl-terminal tail is not involved in the ligand binding however it is necessary for desensitization and internalization [5-7].

\section{Glucagon peptide and its biological action}

Glucagon is a peptide hormone composed of 29-amino acids which is produced and secreted in the $\alpha$-cells of the islets of langerhans in order to maintain normal glucose index by producing hepatic glucose to regulate insulin action [4]. The amino acid sequence of glucagon peptide is shown in Figure 1.

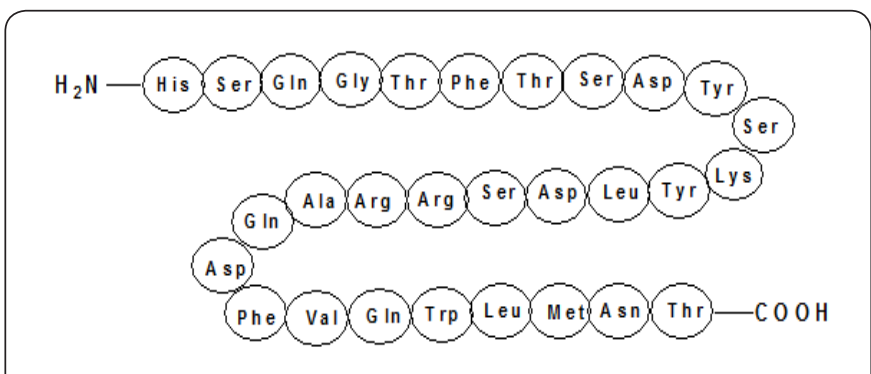

Figure 1: Sequence of amino acids in glucagon peptide.

Glucagon exerts its effects generally in the liver, where it stimulates the biological events such as glycogenolysis, gluconeogenesis, and ketogenesis to raise hepatic glucose 
output. Cyclic adenosine monophosphate (cAMP) actually mediates most of the glucagon's cellular effects. During this process glucagon receptor binds with glucagon peptide to activate adenylyl cyclase via its cognate heterotrimeric $G$ protein Gs to produce cAMP as shown in Figure $2[4,6,8]$.

\section{Antagonists of glucagon receptor}

The production and release of large quantity of glucose from the liver under the action of glucagon receptor is a major cause of hyperglycemia in type- 2 diabetes. During type- 2 diabetes, the level of glucagon is higher than both the insulin and blood glucose levels. In this situation, one of the most effective strategies for the treatment of hyperglycemia in type- 2 diabetes involved development and discovery of new efficient therapeutic agents (antagonists) to block the effect of glucagon on hepatic glucose production [9]. New therapies capable of maintaining normal glucose index for longer period of time without serious side effects are highly desirable [10]. Non-peptide glucagon antagonists of glucagon receptor are valuable because they are orally useful active hypoglycemic agents as body can absorb them properly $[11,12]$.

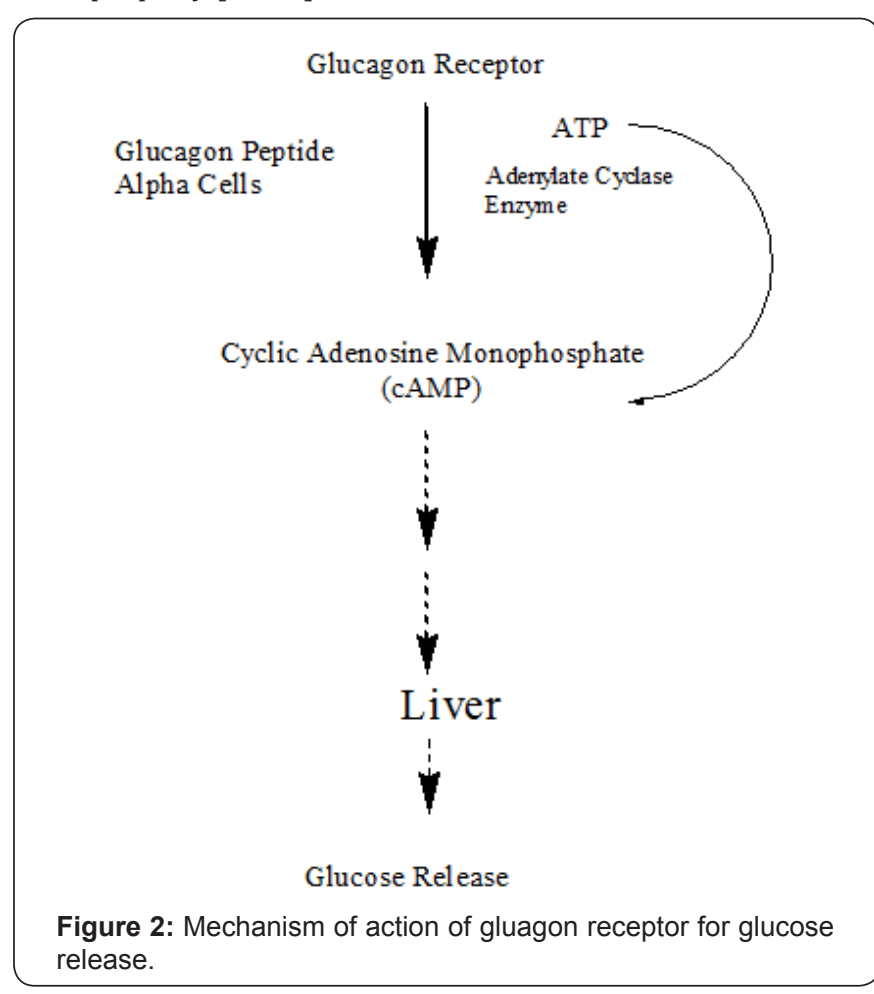

In a study, a series of triarylimidazoles and triarylpyrroles was investigated to discover new non-peptide, orally bioavailabile antagonists of glucagons receptor. Compound 2-(4-Pyridyl)5-(4-chlorophenyl)-3-(5-bromo-2-propyloxyphenyl)pyrrole as shown in Figure 3, exhibited significant inhibition against binding of isotopic labeled glucagon to the human glucagon receptor with an $\mathrm{IC}_{50}=3.7 \pm 63.4 \mathrm{nM}$ [8].

Similarly, in another study, N-[3-cyano-6-(1, 1-dimethylpropyl)-4, 5, 6, 7-tetrahydro-1- enzothien-2-yl]-2ethylbutanamide (compound 2) exhibited potentGCGRantagonist potential by inhibiting ( $\mathrm{IC}_{50}$ of $181 \pm 10 \mathrm{nmol} / \mathrm{l}$ ) the binding of ${ }^{125}$ I-glucagon to the membrane. Whereas, its structurally related analog (compound 3) as shown in Figure 4, was a poor inhibitor $(20 \pm 1.5 \%$ inhibition at $10 \mu \mathrm{mol} / \mathrm{l})$ on glucagon binding assay [13]. The fungal bisanthroquinone skyrin was investigated for its inhibitory potential against glucagon-stimulated production of cAMP in vivo. Skyrin exhibited significant inhibition of cAMP production from rat liver. The mechanism of antagonistic effect of skyrin was non-competitive type for binding of glucagon to its receptor instead it specifically uncoupled glucagon receptor for adenylate cyclase activation. Skyrin and its oxygenated derivative oxyskyrin are shown in Figure 5. Skyrin and oxyskyrin inhibited glucagon stimulation of cAMP production with an $\mathrm{EC}_{50}$ $=42 \mu \mathrm{mol} / \mathrm{L}$ and $\mathrm{EC}_{50}=106 \mu \mathrm{mol} / \mathrm{L}$, respectively $[14,15]$.

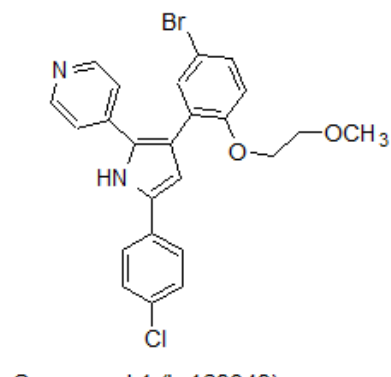

Compound 1 (L-168049)

Figure 3: 2-(4-Pyridyl)-5-(4-chlorophenyl)-3-(5-bromo-2propyloxyphenyl) pyrrole

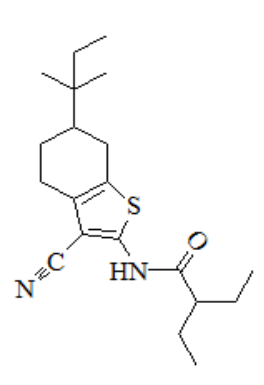

Compound 2

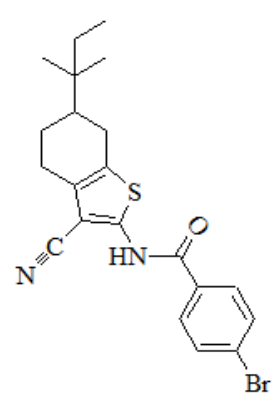

Compound 3
Figure 4: Antagonists of glucagon receptor.<smiles></smiles><smiles>Cc1cc(O)c2c(c1)C(=O)c1c(O)cc(O)cc1C2=O</smiles>

Figure 5: Skyrin and oxyskyrin promsinig antagonists of glucagon receptor 


\section{Current Research in Diabetes \& Obesity Journal}

\section{References}

1. Grover S, Dhanjal JK, Goyal S (2014) Grover A, Sundar D. Computational identification of novel natural inhibitors of glucagon receptor for checking type II diabetes mellitus. BMC bioinformatics 15(Suppl 16): S13.

2. Lagerström MC, Schiöth HB (2008) Structural diversity of G proteincoupled receptors and significance for drug discovery. Nature reviews Drug discovery 7(4): 339-357.

3. Oldham WM, Hamm HE (2008) Heterotrimeric G protein activation by G-protein-coupled receptors. Nature reviews Molecular cell biology 9(1): 60-71.

4. Mayo KE, Miller LJ, Bataille D, Dalle S, Göke B, et al. (2003) International Union of Pharmacology. XXXV. The glucagon receptor family. Pharmacol Rev 55(1): 167-194.

5. Parthier C, Kleinschmidt M, Neumann P, Rudolph R, Manhart S, et al. (2007) Crystal structure of the incretin-bound extracellular domain of a G protein-coupled receptor. Proceedings of the National Academy of Sciences 104(35): 13942-13947.

6. Unson CG (2002) Molecular determinants of glucagon receptor signaling. Biopolymers 66(4): 218-235

7. Brubaker PL, Drucker DJ (2002) Structure-function of the glucagon receptor family of $\mathrm{G}$ protein-coupled receptors: the glucagon, GIP, GLP1, and GLP-2 receptors. Receptors and Channels 8(3-4): 179-188.

8. Cascieri MA, Koch GE, Ber E, Sadowski SJ, Louizides D, et al. (1999)
Characterization of a novel, non-peptidyl antagonist of the human glucagon receptor. J Biol Chem 274(13): 8694-8697.

9. Lagerström MC, Schiöth HB (2008) Structural diversity of G proteincoupled receptors and significance for drug discovery. Nat Rev Drug Discov 7(4): 339-357.

10. Ahrén B (2009) Islet G protein-coupled receptors as potential targets for treatment of type 2 diabetes. Nat Rev Drug Discov 8(5): 369-385.

11. Baig MH, Ahmad K, Hasan Q, Khan MK, Rao NS, et al. (2015) Interaction of glucagon G-protein coupled receptor with known natural antidiabetic compounds: multiscoring in silico approach. EvidenceBased Complementary and Alternative Medicine, p. 6.

12. Tota MR, Xu L, Sirotina A, Strader CD, Graziano MP (1995) Interaction of [fluorescein-Trp25] glucagon with the human glucagon receptor expressed in Drosophila Schneider 2 cells. J Biol Chem 270(44): 26466-26472.

13. Qureshi SA, Candelore MR, Xie D, Yang X, Tota LM, et al. (2004) A novel glucagon receptor antagonist inhibits glucagon-mediated biological effects. Diabetes 53(12): 3267-3273.

14. Parker JC, McPherson RK, Andrews KM, Levy CB, Dubins JS, et al. (2000) Effects of skyrin, a receptor-selective glucagon antagonist, in rat and human hepatocytes. Diabetes 49(12): 2079-2086.

15. Lotfy M, Kalasz H, Szalai G, Singh J, Adeghate E (2014) Recent progress in the use of glucagon and glucagon receptor antago-nists in the treatment of diabetes mellitus. Open Med Chem J 8: 28-35.

\begin{tabular}{l} 
Your next submission with Juniper Publishers \\
will reach you the below assets \\
- Quality Editorial service \\
- Swift Peer Review \\
- Reprints availability \\
- E-prints Service \\
- Manuscript Podcast for convenient understanding \\
- Global attainment for your research \\
- Manuscript accessibility in different formats \\
( Pdf, E-pub, Full Text, Audio) \\
- Unceasing customer service \\
Track the below URL for one-step submission \\
https://juniperpublishers.com/online-submission.php \\
\hline
\end{tabular}

